\title{
Injuries Caused by Citrus Leafminer (Phyllocnistis citrella) Exacerbate Citrus Canker (Xanthomonas axonopodis pv. citri) Infection
}

\author{
Waldir C. Jesus Junior¹, José Belasque Júnior ${ }^{1 *}$, Lilian Amorim²*, Rock Seille C. Christiano², \\ José Roberto P. Parra ${ }^{2} \&$ Armando Bergamin Filho ${ }^{2 *}$ \\ ${ }^{1}$ Departamento Científico, Centro de Pesquisas Citrícolas, Fundecitrus, CEP 14807-040, Araraquara, SP, \\ e-mail: belasque@fundecitrus.com.br; ${ }^{2}$ Departamento de Entomologia, Fitopatologia e Zoologia Agrícola, \\ ESALQ, Universidade de São Paulo, Cx. Postal 9, CEP 13418-900, Piracicaba, SP
}

(Accepted for publication on 11/07/2006)

Author for correspondence: José Belasque Júnior

JESUS JUNIOR, W.C., BELASQUE JÚNIOR, J., AMORIM, L., CHRISTIANO R.S.C., PARRA, J.R.P. \& BERGAMIN FILHO, A. Injuries caused by citrus leafminer (Phyllocnistis citrella) exacerbate citrus canker (Xanthomonas axonopodis pv. citri) infection. Fitopatologia Brasileira 31:277-283. 2006.

\begin{abstract}
After the introduction of citrus leafminer in São Paulo State, an increase in the number of new plants infected with citrus canker has been observed. The interaction between these two organisms is known, but there is no information about how the leafminer damage intensifies citrus canker incidence and severity. The objectives of this paper were to evaluate the effects of leafminer damage in citrus canker infection and its influence on the monocyclic components of the disease on Citrus limonia. Higher incidence of diseased plants, AUDPC (area under the disease progress curve), disease severity and shorter incubation periods were observed in plants inoculated after insect infestation. These factors explain the association found between the higher citrus canker intensity and the damage caused by the insect and show, albeit partially, the consequences of these changes in the spread of the pathogen under natural conditions of infection.
\end{abstract}

Additional keywords: spread, incubation period, insect-pathogen interaction.

\section{RESUMO}

Injúrias da Larva Minadora dos Citros (Phyllocnistis citrella) Intensificam a Infecção por Cancro Cítrico (Xanthomonas axonopodis pv. citri)

Após a constatação da larva minadora dos citros no Estado de São Paulo foi observado um aumento no número de novas plantas infectadas pelo cancro cítrico. Apesar da interação existente entre o cancro cítrico e a larva minadora dos citros ser conhecida já há alguns anos, não há informações que permitam explicar claramente os aumentos observados na incidência e severidade do cancro cítrico quando de sua associação com as injúrias provocadas pelo inseto. Desta forma, no presente trabalho foram avaliados os efeitos de injúrias da larva minadora dos citros na infecção por cancro cítrico e a influência da larva minadora nos componentes monocíclicos da doença em Citrus limonia. Foram observadas maiores incidências de plantas doentes, área abaixo da curva de progresso da doença $(A A C P D)$, severidade da doença e menores períodos de incubação quando a inoculação ocorreu em plantas infestadas pela larva minadora dos citros. Esses fatores explicam a associação encontrada entre a maior intensidade dos sintomas da doença e as injúrias do inseto e revelam, ainda que parcialmente, as conseqüências destas mudanças na disseminação do patógeno sob condições naturais de infecção.

Palavras-chave adicionais: disseminação, período de incubação, interação inseto-patógeno.

\section{INTRODUCTION}

Citrus canker, caused by Xanthomonas axonopodis pv. citri [(Hasse) Vauterin et al.], is one of the most important citrus diseases (Stall \& Seymour, 1983; Gottwald et al., 2001, 2002). The symptoms occur in the form of necrotic lesions on the leaves, stems and fruits. Severe infections may induce defoliation, fruit drop and death of the twigs (Stall

*CNPq Scholarship.
\& Seymour, 1983; Schoulties et al., 1987). Under natural infection conditions, short-distance dissemination occurs due to the action of rainfall splashing and of rainfall associated with winds mainly, and long-distance dissemination occurs due to transportation of infected plant material (Danós et al., 1984; Civerolo, 1985; Gottwald et al., 1988, 1989). International trade imposes restrictions to importation of citrus products from countries that present citrus canker, a quarantine disease for the main producing countries. Due to this reason, Brazil and the United States adopt measures for 
excluding and eradicating the pathogen (Stall \& Civerolo, 1991; Gottwald et al., 2001; Schubert et al., 2001).

The injuries caused by citrus leafminer [Phyllocnistis citrella (Stainton, 1856) (Lepidoptera, Gracillariidae)] exacerbate citrus canker outbreak (Sohi \& Sandhu, 1968; Sinha et al., 1972; Cook, 1988; Venkateswarlu \& Ramapandu, 1992; Chagas et al., 2001). Besides the direct damages induced by this insect, mainly on the leaves of new sprouts, but also high infestations on twigs and fruits (Clausen, 1931; Badawy, 1967; Heppner, 1993; Prates et al., 1996), the direct association with citrus canker has been reported in the literature (Gottwald et al., 1997; Chagas et al., 2001). After the citrus leafminer was first observed in São Paulo state (Prates et al., 1996), an increased number of new plants infected with the disease has been observed, resulting in the modification of the method for eradicating citrus canker on September 1999 (São Paulo, 1999; Gimenes-Fernandes et al., 2000; Chagas et al., 2001).

Phytopathogenic bacteria penetrate into their hosts by means of natural openings, generally the stomata, or by wounds (Crosse et al., 1972; Daft \& Leben, 1972). The injuries induced by leafminer on citrus leaves form a number of new openings through which the pathogen enters the host. After the infection process is established, the symptoms induced coalesce and form large necrotic areas, possibly also as a function of the wounds caused by the insect. Large areas of the host that are occupied by lesions serve as a more effective inoculum source, due to the higher number of bacterial cells present (Gottwald et al., 1988, 1989; Gottwald \& Graham, 1990).

Based on samplings conducted in infested areas in the Republic of Yemen, the occurrence of leaves infected with citrus canker associated to the injuries caused by the insect was observed (Cook, 1988). Frequently, the disease lesions were coincidental with the galleries caused by the leafminer and, less frequently, the lesions were found isolated from the injuries (Sohi \& Sandhu, 1968; Cook, 1988; Venkateswarlu \& Ramapandu, 1992). The insect is not an efficient vector of the bacteria, and the disease is unlikely spread by this way under natural infection conditions (Belasque Júnior et al., 2005). Although the interaction between citrus canker and citrus leafminer has been known for a few years (Sohi \& Sandhu, 1968; Cook, 1988; Venkateswarlu \& Ramapandu, 1992; Gottwald et al., 1997; Chagas et al., 2001), there is no information clearly explaining the increased citrus canker incidence/severity observed when associated with the insect (Graham et al., 1996, 2004; Chagas et al., 2001). Considering these facts, the objectives of this work were (i) to evaluate the effects of injuries caused by different instars of citrus leafminer on citrus canker infection and (ii) to clarify the influence of the leafminer on the monocyclic components of the disease.

\section{MATERIAL AND METHODS}

\section{Effect of instars of citrus leafminer on Xanthomonas axonopodis pv. citri infection}

Plants of rangpur lime [Citrus limonia (L.) Osbeck] measuring $20-25 \mathrm{~cm}$ in height were cultivated in plastic tubes $(20 \times 2.7 \mathrm{~cm})$ containing vermiculite and organic substrate $(1: 1)$ in green house conditions. Fifteen to twenty days after cutting, the plants were left at the disposal of adult citrus leafminers for two days for egg-laying under laboratory conditions at $25 \pm 1{ }^{\circ} \mathrm{C}, 70 \pm 10 \%$ relative humidity, and photophase for fourteen hours (Chagas \& Parra, 2000). After egg-laying, the plants were transferred to incubators at temperatures from $18{ }^{\circ} \mathrm{C}$ to $32{ }^{\circ} \mathrm{C}$ to obtain leaves infested with different stages of the insect simultaneously (Chagas, 1999). Ten plants with each phase of the leafminer (eggs, first, second, third and fourth instars larvae and pupae) were inoculated by spraying a suspension of Xanthomonas axonopodis pv. citri (Xac) containing approximately $10^{6}$ colony-forming units per milliliter $(\mathrm{CFU} / \mathrm{mL})$. For comparison purposes, ten plants that had been mechanically wounded with a needle immediately before inoculation, and another ten plants that had not been wounded, were also inoculated, totalizing eight treatments of a completely randomized outlining and ten replicates. The plants that had been mechanically wounded presented from three to seven leaves with four to ten wounds each. All plants were sprayed with the bacterial suspension up to saturation and were kept in a wet chamber for 96 hours after inoculation. After being removed from the wet chamber, all plants were kept in polystyrene boxes (length $\mathrm{x}$ width $\mathrm{x}$ height $=60 \times 40 \times 50$ $\mathrm{cm}$ ) under laboratory conditions at the temperature of $28 \pm 2$ ${ }^{\circ} \mathrm{C}, 90 \pm 10 \%$ relative humidity, and photophase for fourteen hours. The experiment was repeated once.

\section{Comparison of the age of the lesions caused by Xanthomonas axonopodis pv. citri infection}

The same experimental conditions previously described were used for this second series of experiments. In a first stage, plants with eggs laid by leafminer adults were successively inoculated, starting on the expected day of hatching and completed four days after the expected day of hatching (DEL). Each treatment corresponded to the inoculation of plants one, two, three, and four days after hatching or simultaneously. Five other treatments, formed by plants that had been mechanically wounded by needles on the same hatching day as the other treatments and in the same manner, were used for comparison. The outlining of the experiment was completely randomized, with ten treatments and ten replicates (plants) each. The experiment was repeated once.

Under the experimental conditions used, the development of citrus leafminer larvae lasts for approximately eight to ten days, and therefore a second experiment was installed, and plants up to 12 DEL were inoculated. The total of treatments tested was 19,13 of which were formed by plants wounded by the leafminer and inoculated from zero to $12 \mathrm{DEL}$, and another six formed by plants mechanically wounded, inoculated from zero to five days after the wounds. The experiment was repeated once.

\section{Data evaluations and analysis}


As of four days after inoculation, all plants were evaluated daily as to the presence of citrus canker symptoms. The treatments were compared among themselves as to the incidence of diseased plants, mean incubation period, area under the disease progress curve $(A U D P C)$ and severity. The mean incubation period was considered the number of days after inoculation until at least one citrus canker injury, visible with the naked eye, per plant, occurred. Each plant was considered a replicate, and the data presented refer to the mean number of days/treatment.

The AUDPC was calculated by the trapezoidal integration of the disease incidence in time, considering the whole period evaluated, as follows:

$$
A U D P C=\sum_{i=1}^{n-1}\left(\frac{X_{i}+X_{i+1}}{2}\right)\left(t_{i+1}-t_{i}\right)
$$

where $X$ is the disease incidence (percentage of plants diseased), $n$ the number of evaluations, and $\left(t_{i+1}-t_{i}\right)$ the time interval (days) between two consecutive evaluations (Campbell \& Madden, 1990). For the calculations, the incidence data collected up to 11 days after inoculation for the first series of experiments (effect of leafminer larvae instars) up to 20 days for the second series (comparison of the age of the lesions) were considered.

Fifteen days after inoculation of the first series of experiments, ten symptomatic leaves for each treatment were collected at random, for evaluation of disease severity. Each leaf was scanned and severity was determined using Quant software (Vale et al., 2001). The treatments were compared by variance analysis ( $F$ test) to identify significant differences in the incubation period and severity variables, and the corresponding means were compared according to Tukey's test $(P=0,05)$. The data obtained for both experiments were analyzed together. The statistical analyses were processed using the Statistica 6.0 software.

For the second series of experiment, citrus canker severity was evaluated on leaves collected 20 days after inoculation of the plants. The mean data for the incubation period and severity for both experiments with plants inoculated up to 12 DEL were analyzed together by variance analysis and Tukey test (Statistica 6.0).

\section{RESULTS}

\section{Effect of citrus leafminer instars on Xanthomonas axonopodis pv. citri infection}

The presence of wounds in the plants played a major role in the infection caused by citrus canker. Only the plants infested with first and second instars larvae presented 100\% incidence, which occurred 12 and 10 days after inoculation, respectively (Figure 1, and data not presented). The maximum incidence on the plants that had been mechanically wounded was $80 \%$, observed ten days after inoculation. In the absence of wounds, only $10 \%$ of the plants showed symptoms of the disease, and the plants inoculated by the time they were

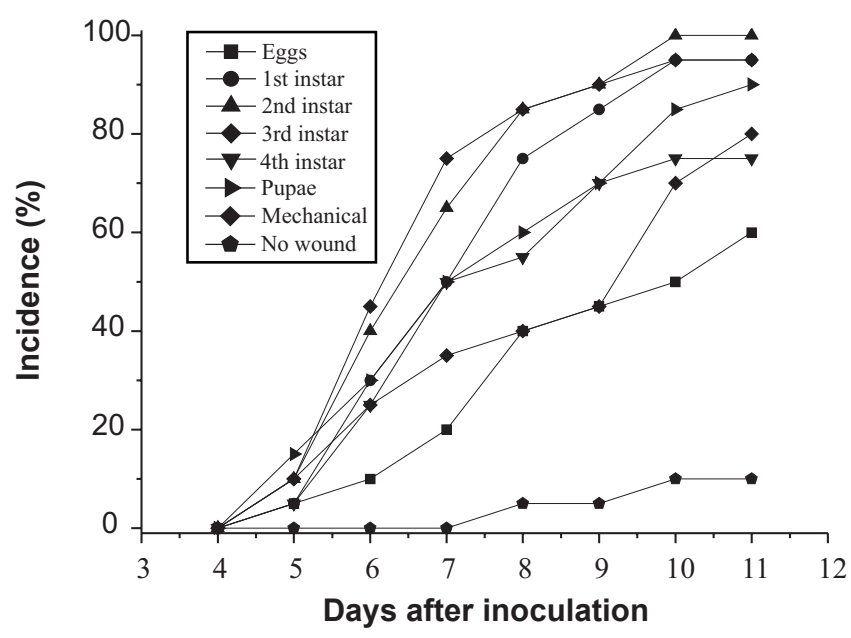

FIG. 1 - Incidence of rangpur lime (Citrus limonia) plants with citrus canker (Xanthomonas axonopodis pv. citri) inoculated when infested with eggs, larvae or pupae of citrus leafminer (Phyllocnistis citrella), mechanically wounded or not wounded.

infested with insect eggs presented at most $60 \%$ of incidence of diseased plants, 11 days after inoculation.

The mean incubation period varied from 6.8 to 8.6 days and only the treatment formed by plants infested with eggs differed significantly from the other treatments (Table 1). The plants infested with third instar larvae were those that presented symptoms within the shortest time frame. Because only $10 \%$ of plants inoculated without wounds presented symptoms, this treatment was not used in the statistical analysis for comparison of the incubation period. The differences observed during the incubation period between the treatments were similar to those observed in the $A U D P C$. The highest values were noted in the plants inoculated when

TABLE 1 - Incubation period, area under the disease progress curve of incidence $(A U D P C)$ and severity of citrus canker (Xanthomonas axonopodis pv. citri) in rangpur lime (Citrus limonia) plants inoculated when infested with eggs, larvae or pupae of citrus leafminer (Phyllocnistis citrella), mechanically wounded or not wounded

\begin{tabular}{lccc}
\hline \hline Treatments & $\begin{array}{c}\text { Incubation } \\
\text { period (days) }\end{array}$ & AUDPC $^{1}$ & Severity (\%) \\
\hline Eggs & $8.54 \mathrm{a}^{2}$ & 200 & $0.27 \mathrm{~d}$ \\
First instar & $7.42 \mathrm{~b}$ & 388 & $0.68 \mathrm{~cd}$ \\
Second instar & $7.10 \mathrm{~b}$ & 440 & $1.13 \mathrm{bc}$ \\
Third instar & $6.79 \mathrm{~b}$ & 448 & $1.49 \mathrm{ab}$ \\
Fourth instar & $7.27 \mathrm{~b}$ & 318 & $1.93 \mathrm{a}$ \\
Pupae & $7.79 \mathrm{~b}$ & 355 & $1.21 \mathrm{bc}$ \\
Mechanical wounds & $8.67 \mathrm{~b}$ & 265 & $0.37 \mathrm{~d}$ \\
Leaves with no wounds & $9.00^{3}$ & 25 & - \\
\hline $\mathrm{F}(P)$ & $6.60(<0.0001)$ & - & $6.19(<0.0001)$ \\
\hline
\end{tabular}

${ }^{1}$ Means of two experiments.

${ }^{2}$ Means followed by the same letter in the columns do not differ at $5 \%$ probability according to Tukey's test.

${ }^{3}$ The data for this treatment were not considered for the statistical analysis due to the low number of symptomatic plants. 
infested with second and third instars larvae, followed by plants with first instar larvae. The lowest values were found for plants infested with eggs and without wounds.

The presence of leafminer wounds also increased citrus canker severity. The highest severity was observed in the plants infested with third and fourth instar larvae. Plants infested with pupae and second instar larvae presented similar severities. The lowest severities of the disease occurred in plants infested with first instar larvae, eggs and those that received mechanical wounds. No significant differences were detected between the last three treatments. The treatment formed by plants that were inoculated without wounds was excluded from the severity data analysis.

\section{Comparison of age of injuries caused by Xanthomonas axonopodis pv. citri infection}

The highest incidences of diseased plants occurred in the treatments consisting of plants inoculated up to six DEL or on the day when the mechanical wounds were made (data not presented). The evolution of the symptoms was faster in the plants that were inoculated simultaneously to the mechanical wound and to the hatching of leafminer eggs (Figure 2). It took virtually twice for the plants inoculated in the fourth DEL to reach $100 \%$ of incidence. After 14 days, the incidence in the treatments inoculated one day after the mechanical wounds was $80 \%$. Inoculation two or three days after the mechanical wounds resulted in $40 \%$ and $30 \%$ incidence, respectively, observed as of 15 days after inoculation, similar to the observation for the infested plants that were inoculated after 12 days. The plants that had been mechanically wounded four and five days before inoculation
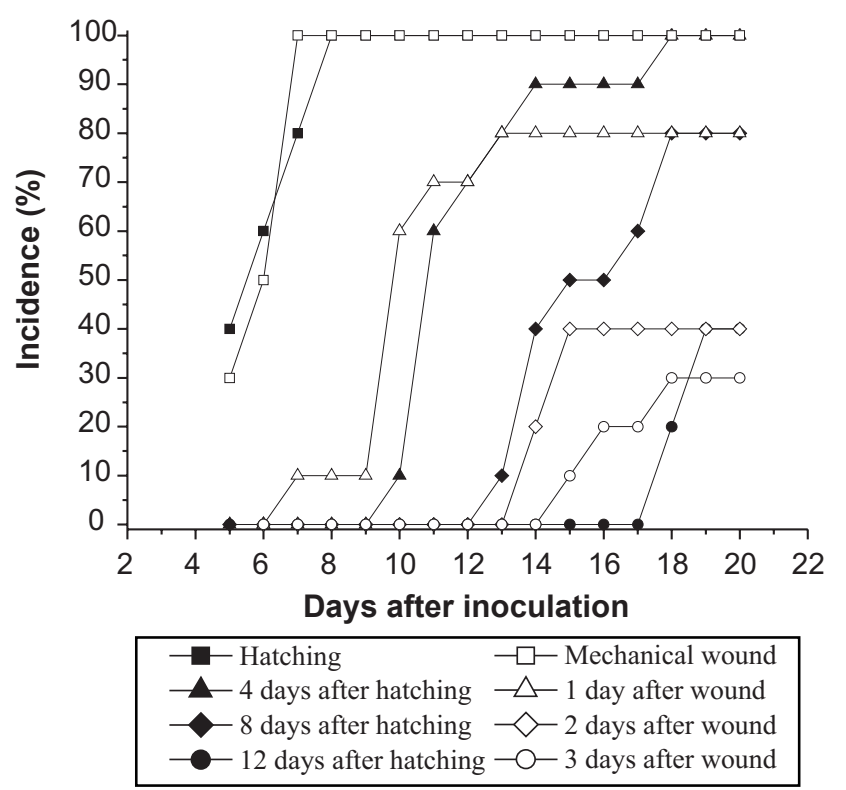

FIG. 2 - Incidence of rangpur lime (Citrus limonia) plants with citrus canker (Xanthomonas axonopodis pv. citri) inoculated on different days after hatching of the first instar of citrus leafminer (Phyllocnistis citrella), or mechanically wounded. with the bacterium did not present symptoms of the disease during the whole experimental period, which extended up to 31 days after inoculation (data not presented). The plants wounded three days before inoculation presented symptoms in only one of the experiments.

The mean incubation period varied from 6.6 to 24.6 days and the shortest periods were observed in the plants inoculated in the hatching day or when the mechanical wounds were made (Table 2). The delay of one and two days in the inoculation of the plants mechanically wounded resulted in incubation periods three and ten days longer, respectively. The same behavior occurred for inoculations made on plants infested with the leafminer, but with a less decreased incubation period. Long incubation periods, near or higher than 20 days, occurred when inoculations were made as of the ninth DEL. Similarly, a gradual decrease of $A U D P C$ values was observed with the increased number of days between larvae hatching, or the mechanical wounds, and inoculation. The inoculation of the plants after nine and ten DEL resulted in $A U D P C$ values similar to those obtained with plants inoculated two days after being wounded. In spite of the differences between the severity values of the disease in leaves inoculated when infested with the leafminer and those mechanically wounded, in absolute terms, significant

TABLE 2 - Incubation period, area under the disease progress curve of incidence $(A U D P C)$ and severity of citrus canker (Xanthomonas axonopodis pv. citri) in rangpur lime (Citrus limonia) plants inoculated on different days after hatching of the first instar of citrus leafminer (Phyllocnistis citrella), or mechanically wounded

\begin{tabular}{|c|c|c|c|}
\hline Treatments & $\begin{array}{l}\text { Incubation } \\
\text { period (days) }\end{array}$ & AUDPC $^{1}$ & Severity $(\%)$ \\
\hline Day of hatching & $7.20 \mathrm{ij}^{2}$ & 1430 & $2.95 \mathrm{abcd}$ \\
\hline 1 day after ha tching & 10.05 ghij & 875 & $2.65 \mathrm{abcd}$ \\
\hline 2 days after hatching & $10.88 \mathrm{ghi}$ & 631 & $2.21 \mathrm{abcd}$ \\
\hline 3 days after hatching & $12.63 \mathrm{fg}$ & 715 & $3.01 \mathrm{abcd}$ \\
\hline 4 days after hatching & $11.85 \mathrm{gh}$ & 821 & $3.08 \mathrm{abcd}$ \\
\hline 5 days after hatching & $12.55 \mathrm{fg}$ & 921 & $3.40 \mathrm{abcd}$ \\
\hline 6 days after hatching & $14.15 \mathrm{ef}$ & 820 & $3.09 \mathrm{abcd}$ \\
\hline 7 days after hatching & 15.10 ef & 575 & $3.56 \mathrm{abcd}$ \\
\hline 8 days after hatching & $15.17 \mathrm{ef}$ & 410 & $4.87 \mathrm{a}$ \\
\hline 9 days after hatching & $19.56 \mathrm{bc}$ & 250 & $4.55 \mathrm{ab}$ \\
\hline 10 days after hatching & $19.00 \mathrm{bcd}$ & 235 & $3.93 \mathrm{abc}$ \\
\hline 11 days after hatching & $20.31 \mathrm{~b}$ & 75 & $3.25 \mathrm{abcd}$ \\
\hline 12 days after hatching & $24.58 \mathrm{a}$ & 80 & $1.67 \mathrm{abcd}$ \\
\hline $\begin{array}{l}\text { Day of mechanical } \\
\text { wound }\end{array}$ & $6.60 \mathrm{j}$ & 1430 & $0.98 \mathrm{bcd}$ \\
\hline $\begin{array}{l}1 \text { day after mechanical } \\
\text { wound }\end{array}$ & $9.72 \mathrm{hij}$ & 830 & $1.21 \mathrm{abcd}$ \\
\hline $\begin{array}{l}2 \text { days after mechanical } \\
\text { wound }\end{array}$ & $16.71 \mathrm{de}$ & 240 & $0.56 \mathrm{~cd}$ \\
\hline $\begin{array}{l}3 \text { days after mechanical } \\
\text { wound }\end{array}$ & $16.33^{3}$ & 125 & $0.08 \mathrm{~d}$ \\
\hline $\mathrm{F}(P)$ & $70.98(<0.0001)$ & - & $3.22(<0.0001)$ \\
\hline
\end{tabular}

${ }^{1}$ Data from one experiment.

${ }^{2}$ Means followed by the same letter in the columns do not differ at $5 \%$ probability according to Tukey's test.

${ }^{3}$ The data for this treatment were not considered for the statistical analysis due to the low number of symptomatic plants. 
differences occurred only in a few of the treatments tested. Mean severities higher than $4 \%$ corresponded to plants inoculated at eight and nine DEL, while severities between 2 and $3 \%$ were observed in plants inoculated at zero to three DEL. The inoculation of the plants mechanically wounded in the same periods resulted in severities close to or lower than $1 \%$.

\section{DISCUSSION}

The intensity of the disease increased with the presence of the injuries caused by citrus leafminer. The symptoms of the disease appeared more rapidly, the ratio of plants diseased and the severity were higher, and the tissues remained susceptible for a longer period. These factors explain the association found between the intensity of the disease symptoms and the injuries caused by the insect (Sohi \& Sandhu, 1968; Cook, 1988; Venkateswarlu \& Ramapandu, 1992; Chagas et al., 2001). Bacterial infection is more severe when there is some kind of injury in their hosts, and the extent of these injuries may be of epidemiological importance (Pohronezny et al., 1992). The importance of the mechanical wounds on Xac infection was previously shown under experimental conditions (Vernière et al., 2003). Whereas the inoculation of tissues at different ages, in the presence of wounds, resulted in small differences at to the expression of the symptoms, the incidence of tissues diseased was three to six times lower when they were absent.

During the inoculation of the plants in the experiments herein reported, natural conditions of the infection process caused by Xac were simulated. All plants were inoculated with a bacterial suspension at $10^{6} \mathrm{UFC} / \mathrm{mL}$, considered the threshold for artificial inoculations (Beattie $\&$ Lindow, 1995). The inoculation by spray reproduced the most common mechanism for pathogen dissemination that occurs by rainfall splash and wind-driven rainfall (Gottwald et al., 1989). The action of wind speeds in excess of $8 \mathrm{~m} / \mathrm{s}$ induces wounds on the leaves, twigs and fruits, which may result in significant increase of the disease (Gottwald et al., 1988). The mechanical wounds made on the plants before inoculation simulated these wounds that occur on the leaves under natural epidemic conditions.

The concentration of bacterial cells may alter the incubation period, and the more rapid expression of the symptoms is induced by higher concentrations of inoculum (Beattie \& Lindow, 1995). During the feeding process, the leafminer damages and exposes the leaf mesophyll, increasing the probability of a direct contact of the pathogen with the interior of the host. Although the extent of the injuries is directly related to the insect development, reaching its peak at pupae stage, the highest probability occurs when the leaves present second and third instars larvae of the leafminer. Fourth instar larvae and pupae can cause the leaf to twist, reducing the surface exposed to bacteria deposition. A second explanation is that the bacterial cells, in the presence of wounds, enter directly into contact with the interior of leaf tissues, and the pre-penetration phase, characterized by the multiplication in the host's surface, is suppressed. As a result, penetration and infection occur more rapidly compared to intact tissues.

The higher extension of injuries allow not only the highest incidences but, as other authors have observed (Chagas et al., 2001), these highest incidences also occur more rapidly in time. The combination of these two components is expressed in values of $A U D P C$, which considers several of the characteristics associated to an epidemic and reveals a quantitative measure to express the symptoms (Vernière $e t$ al., 2003). In plants inoculated when infested with leafminer eggs, the incidences and $A U D P C$ means were higher than in non-injured plants. The plants inoculated with eggs did not present injuries, but these occurred one to two days after inoculation, as a result of the hatching of first instar larvae (Chagas \& Parra, 2000). Therefore, the bacterial cells present on leaf surface were able to enter into directly contact with the tissues damaged by the recently emerged larvae. Keeping the plants in a wet chamber for 96 hours after inoculation allowed the survival of several bacterial cells days after inoculation.

Citrus canker severity was higher in the plants that were inoculated in the presence of fourth instar larvae and pupae. In the experiments designed to compare the age of the wounds, the treatments with plants infested with the insect did not differ statistically among themselves, although the highest absolute values occurred in plants inoculated eight and nine DEL. These results differ from those obtained as to incubation period, incidence of plants and $A U D P C$, in which the infections were more severe on the plants infected with the initial immature stages (up to the third instar). Severity evaluations were performed 15 days after inoculation of the experiments designed to evaluate the effect of different instars and 20 days for the other experiments. In these dates, the leaves that showed symptoms of plants inoculated with fourth instar larvae and pupae were more twisted and deformed than the leaves of the other treatments due to the more advanced development stages of the insect. Consequently, total foliar area was greatly reduced, resulting in higher severities in these treatments.

The differences observed in the treatments corresponding to the age of the wounds caused by the leafminer and those mechanical are partially due to the larvae development of the insect that lasts several days. The inoculations made days after hatching of the larvae promoted the contact between the pathogen and the host in the presence of wounds. Under the experimental conditions evaluated, larvae hatching occurs in the mean of one to two days after egg laying, the larvae stage lasts for four days and pupae stage lasts eight days, approximately (Chagas $\&$ Parra, 2000). Therefore, the inoculations on day zero corresponded to the egg stage, the inoculations on day two corresponded to the second instar, and the inoculations on four/five DEL corresponded to the initial pupae stage. During the development of the immature stages of the insect, 
injuries on foliar tissues continuously increase up to the end of the fourth instar. Even though, inoculations in plants up to 12 DEL resulted in symptoms of the disease, indicating the occurrence of infection approximately six days after the pupae stage was reached, when new wounds do not occur anymore. According to Goto (1990), wounds caused in a drastic way, such as mechanical wounds, heal more quickly, within a few days, whereas wounds caused by the leafminer heal more slowly, making leaf tissues susceptible to infection for longer periods.

The increased incidence of plants with citrus canker observed in Brazil, and also in other countries, occurred as a function of changes in the Xac infection process (Gimenes-Fernandes et al., 2000; Gottwald et al., 2001; Graham et al., 2004). The occurrence of injuries caused by the insect represents several new points for the pathogen to enter and, in a second moment, allow the coalescence of the lesions (Graham et al., 1996, 2004; Gottwald et al., 1997). Larger areas of the host occupied by the disease symptoms can represent additional sources of inoculum (bacterial cells) that can be disseminated (Gottwald et al., 1988, 1989; Gottwald \& Graham, 1990). Considering the hypothesis established by these authors and the experimental data herein presented, it can be concluded that: a) the injuries caused by the leafminer increase the incidence of the disease, impacting the $A U D P C$; b) the plants infested with the leafminer and infected with Xac present symptoms of the disease more rapidly when compared with infections that occur in the absence of wounds. The decreased incubation period, which has the same significance as the latency period in this pathosystem, causes a higher number of disease cycles, with relevant epidemiological consequences; c) the diseased tissues present higher severities and, as a consequence, larger bacterial populations are prone to disseminate in the same plant and neighboring plants; d) the injuries caused by the insect take a long time to heal and allow infections for longer periods, of several days, whereas mechanical wounds heal in approximately three days.

The change caused by the introduction of citrus leafminer in the Xac infection process had important consequences in the campaigns for citrus canker eradication in Brazil and in Florida (Gottwald et al., 1997, 2001, 2002; Gimenes-Fernandes et al., 2000; Chagas et al., 2001). The presence of the citrus leafminer changed the spatial pattern of citrus canker in São Paulo (Bergamin Filho et al., 2000). Previously, citrus canker presented more aggregated distribution patterns. Afterwards, less aggregate patterns were observed, together with the more common presence of satellite foci, more distant from the initial foci of the disease in the plot. The experimental results presented herein refer to changes that occurred in the monocyclic components of the disease, but the consequences of these changes on time and space patterns of the disease still need to be investigated (Bergamin Filho et al., 2000).

\section{ACKNOWLEDGEMENTS}

This research was partially funded by Fundação de Amparo à Pesquisa do Estado de São Paulo (FAPESP) and by Fundecitrus.

\section{LITERATURE CITED}

BADAWY, A. The morphology and biology of Phyllocnistis citrella Stainton, a citrus leaf-miner in the Sudan. Bulletin Society Entomology Egypt 51:95-103. 1967.

BEATTIE, G.A. \& LINDOW, S.E. The secret life of foliar bacterial pathogens on leaves. Annual Review Phytopathology 33:145-172. 1995.

BELASQUE JÚNIOR, J., PARRA-PEDRAZZOLI, A.L., RODRIGUES NETO, J., YAMAMOTO, P.T., CHAGAS, M.C.M., PARRA, J.R.P., VINYARD, B.T. \& HARTUNG, J.S. Adult citrus leafminers (Phyllocnistis citrella) are not efficient vectors for Xanthomonas axonopodis pv. citri. Plant Disease 89:590-594. 2005.

BERGAMIN FILHO, A., AMORIM, L., LARANJEIRA, F.F. \& GOTTWALD, T.R. Epidemiology of citrus canker in Brazil with and without the asian citrus leafminer. Proceedings, $1^{\text {st }}$. International Citrus Canker Research Workshop, Fort Pierce. 2000. p. 6.

CAMPBELL, C.L. \& MADDEN, L.V. Introduction to plant disease epidemiology. New York. John Wiley \& Sons. 1990.

CHAGAS, M.C.M. \& PARRA, J.R.P. Phyllocnistis citrella Stainton (Lepidoptera: Gracillariidae): técnica de criação e biologia em diferentes temperaturas. Anais Sociedade Entomológica Brasileira 29:227-235. 2000.

CHAGAS, M.C.M. Phyllocnistis citrella Stainton, 1856 (Lepidoptera: Gracillariidae): bioecologia e relação com o cancro cítrico. (Tese de Doutorado.) ESALQ, Universidade de São Paulo. Piracicaba SP. 1999.

CHAGAS, M.C.M., PARRA, J.R.P., NAMEKATA, T., HARTUNG, J.S. \& YAMAMOTO, P.T. Phyllocnistis citrella Stainton (Lepidoptera: Gracillariidae) and its relationship with the citrus canker bacterium Xanthomonas axonopodis pv. citri in Brazil. Neotropical Entomology 30:55-59. 2001.

CIVEROLO, E.L. Citrus bacterial canker disease: The bacterium Xanthomonas campestris pv. citri. Citrus canker: An international perspective. Citrus Research and Education Center, University of Florida, Lake Alfred. 11-17, 1985.

CLAUSEN, C.P. Two citrus leafminers of the far east. Technical Bulletin of the USDA. V. 252. 1931.

COOK, A.A. Association of citrus canker pustules with leaf miner tunnels in North Yemen. Plant Disease 72:546. 1988.

CROSSE, J.E., GORDIAN, R.N. \& SHAFFER, W.H. Leaf damage as a predisposing factor in the infection of apple shoots by Erwinia amylovora. Phytopathology 62:176-182. 1972.

DAFT, G.C. \& LEBEN, C. Bacterial blight of soybeans: Epidemiology of blight outbreaks. Phytopathology 62:57-62. 1972.

DANÓS, E., BERGER, R.D. \& STALL, R.E. Temporal and spatial spread of citrus canker within groves. Phytopathology 74:904-908. 1984. 
GIMENES-FERNANDES, N., BARBOSA, J.C., AYRES, A.J. \& MASSARI, C.A. Plantas doentes não detectadas nas inspeções dificultam a erradicação do cancro cítrico. Summa Phytopathologica 26:320-325. 2000.

GOTO, M. Fundamentals of bacterial plant pathology. San Diego CA. Academic Press. 1990.

GOTTWALD, T.R. \& GRAHAM, J.H. Spatial pattern analysis of epidemics of citrus bacterial spot in Florida citrus nurseries. Phytopathology 80:181-190. 1990.

GOTTWALD, T.R., GRAHAM, J.H. \& SCHUBERT, T.S. An epidemiological analysis of the spread of citrus canker in urban Miami, Florida, and synergistic interaction with Asian citrus leafminer. Fruits 52:383-390. 1997.

GOTTWALD, T.R., HUGHES, G., GRAHAM, J.H., SUN, X. \& RILEY, T. The citrus canker epidemic in Florida: the scientific basis of regulatory eradication policy for an invasive species. Phytopathology 91:30-34. 2001.

GOTTWALD, T.R., MCGUIRE, R.G. \& GARRAN, S. Asiatic citrus canker: Spatial and temporal spread in simulated new planting situations in Argentina. Phytopathology 78:739-745. 1988.

GOTTWALD, T.R., SUN, X., RILEY, T., GRAHAM, J.H., FERRANDINO, F. \& TAYLOR, E.L. Geo-referenced spatiotemporal analysis of the urban citrus canker epidemic in Florida. Phytopathology 92:361-377. 2002.

GOTTWALD, T.R., TIMMER, L.W. \& MCGUIRE, R.G. Analysis of disease progress of citrus canker in nurseries in Argentina. Phytopathology 79:1276-1283. 1989.

GRAHAM, J.H., GOTTWALD, T.R., BROWNING, H.W. \& ACHOR, D.S. Citrus leafminer exacerbated the outbreak of Asiatic citrus canker in South Florida. Proceedings, International Conference on Citrus leafminer, Orlando, University of Florida, 1996. p. 83.

GRAHAM, J.H., GOTTWALD, T.R., CUBERO, J. \& ACHOR, D.S. Xanthomonas axonopodis pv. citri: factors affecting successful eradication of citrus canker. Molecular Plant Pathology 5:1-15. 2004.

HEPPNER, J. B. Citrus leaf miner, Phyllocnistis citrella, in Florida (Lepidoptera:Gracillariidae:Phyllocnistinae). Tropical Lepidoptera 4:49-64. 1993.

POHRONEZNY, K., HEWITT, M., INFANTE, J. \& DATNOFF, L. Wind and wind-generated sand injury as factors in infection of pepper by Xanthomonas campestris pv. vesicatoria. Plant Disease 76:1036-1039. 1992.

PRATES, H.S., NAKANO, O. \& GRAVENA, S. "Minadora das folhas de citros" Phyllocnistis citrella, Stainton, 1856. Campinas SP. CATI. Comunicado Técnico, 129. 1996.

SÃO PAULO. Leis, decretos, etc. Portaria da Coordenadoria de Defesa Agropecuária (CDA) n ${ }^{\circ} 17$ de 06 de Agosto de 1999. Diário Oficial, 07 de Agosto de 1999. Seção 1, p.14. Dispõe sobre a erradicação do cancro cítrico.

SCHOULTIES, C.L., CIVEROLO, E.L., MILLER, J.W., STALL, R.E., KRASS, C.J., POE, S.R. \& DUCHARME, E.P. Citrus canker in Florida. Plant Disease 71:388-395. 1987.

SCHUBERT, T.S., RIZVI, S.A., SUN, X., GOTTWALD, T.R., GRAHAM, J.H. \& DIXON, W.N. Meeting the challenge of eradicating citrus canker in Florida - Again. Plant Disease 85:340356. 2001.

SINHA, M. K., BATRA, R. C. \& UPPAL, D. K. Role of citrus leaf-miner (Phyllocnistis citrella Stainton (sic) on the prevalence and severity of citrus canker (Xanthomonas citri (Hasse) Dowson). Madras Agricultural Journal 59:240-245. 1972.

SOHI, G. S. \& SANDHU, M. S. Relationship between citrus leafminer (Phyllocnistis citrella Stainton) injury and citrus canker [Xanthomonas citri (Hasse) Dowson] incidence on citrus leaves. Journal Research Punjab Agricultural University 5:66-69. 1968.

STALL, R.E. \& SEYMOUR, C.P. Canker, a threat to citrus in the gulf-coast states. Plant Disease 67:581-585. 1983.

STALL, R.E. \& CIVEROLO, E.L. Research relating to the recent outbreak of citrus canker in Florida. Annual Review Phytopathology 29:339-420. 1991.

VALE, F.X.R., FERNANDES FILHO, E.I., LIBERATO, J.R. \& ZAMBOLIM, L. Quant - A software to quantify plant disease severity. International Workshop on Plant Disease Epidemiology 8:160. Ouro Preto MG, Brazil. 2001.

VENKATESWARLU, C. \& RAMAPANDU, S. Relationship between incidence of canker and leafminer in acid lime and sathgudi sweet orange. Indian Phytopathology 45:227-228. 1992.

VERNIÈRE, C.J., GOTTWALD, T.R. \& PRUVOST, O. Disease development and symptom expression of Xanthomonas axonopodis pv. citri in various citrus plant tissues. Phytopathology 93:832-843. 2003. 